\title{
The role of the peridomiciliary area in the elimination of Triatoma infestans from rural Argentine communities ${ }^{1}$
}

\author{
María C. Cecere,,$^{2}$ Ricardo E. Gürtler, ${ }^{3}$ Delmi Canale, ${ }^{4}$ \\ Roberto Chuit, ${ }^{5}$ and Joel E. Cohen ${ }^{6}$
}

\begin{abstract}
The purpose of this study was to identify the origin of Triatoma infestans reinfestation and study its dynamics following spraying with deltamethrin inside and around 94 houses in three rural communities in northwestern Argentina. The effectiveness of the spraying was evaluated immediately after the houses were sprayed and two months later. In addition, five residual peridomiciliary foci were found and sprayed, as well as three preexisting ones that had not been sprayed. To monitor reinfestation, biosensors were placed in the houses and each family was also asked to capture triatomines and keep them in plastic bags; in addition, triatomines were searched for in and around houses, using an aerosol that dislodged them from their hiding places. Selective sprayings were carried out only where a colony of $\mathrm{T}$. infestans was found. During the 30 months of follow-up, the percentage of houses in which any T. infestans were captured varied between $3 \%$ and $9 \%$. In six houses, T. infestans were captured during more than one evaluation. The number of peridomiciliary areas found to be infested (19) was double the number of infested houses (9). Colonies of T. infestans were found only in the peridomiciliary areas, where the number of $\mathrm{T}$. infestans captured was six times higher than in the houses. Chickens were the host most frequently associated with peridomiciliary foci. This area was the origin and principal source of reinfestation. To reduce the speed of reinfestation and the frequency with which sprayings are needed, the following environmental and chemical control methods must be combined in the peridomiciliary area: reduce the number of hiding places of triatomines; restrict the raising of birds to structures that cannot be colonized by triatomines; apply an insecticide that is less likely to be degraded by exposure to the elements, or perform a second spraying 6 to 12 months after the first; and employ a device for early detection of the presence of $\mathrm{T}$. infestans around houses.
\end{abstract}

1 Published in Spanish in the Boletin de la Oficina Sanitaria Panamericana, 1996, Vol. 121, No. 1, pp. 1-10, with the title "El papel del peridomicilio en la eliminación de Triatoma infestans de comunidades rurales argentinas."

2 General Ecology Laboratory, Biology Department, University of Buenos Aires. Mailing Address: Laboratorio de Ecología General, Departamento de Biología, Facultad de Ciencias Exactas y Naturales, Universidad de Buenos Aires, Ciudad Universitaria, 1428 Buenos Aires, Argentina.

3 General Ecology Laboratory, Biology Department, University of Buenos Aires, Buenos Aires, Argentina; and Laboratory of Populations, Rockefeller University, New York, New York, U.S.A.

4 Chagas' Disease Reservoirs and Vectors Unit, National Chagas' Disease Service, Córdoba, Argentina.
Triatoma infestans, the principal vector of Chagas' disease, is found in seven Latin American countries (1). This species is vulnerable to classic vector control techniques because of its low rate of proliferation (2), its restriction to domiciliary and peridomiciliary habi-

\footnotetext{
Ministry of Health and Social Action, Bureau of Epidemiology, Buenos Aires, Argentina.

6 Laboratory of Populations, Rockefeller University, New York, New York, U.S.A.
}

tats (3), and its marked susceptibility to modern insecticides. In 1991 a program known as the Iniciativa de los Países del Cono Sur (Southern Cone Countries' Initiative) was launched for the purpose of eliminating Chagas' disease and T. infestans by the year 2000 (4).

Pyrethroids, primarily deltamethrin, have been used since the 1980s to control Chagas' disease vectors. However, two field tests employing deltamethrin detected domiciliary reinfes- 
tation by $T$. infestans in less than one year after spraying $(5,6)$. In the absence of other effective control measures, reinfestation progressed exponentially until the infestation levels observed before spraying were reached (7). In a similar vein, three to five years of surveillance and retreatment of reinfested houses in rural communities of northeastern Argentina did not succeed in eliminating T. infestans $(8,9)$. These and similar studies have highlighted the difficulties confronting attempts to eliminate $T$. infestans from rural communities.

In view of the lack of $T$. infestans foci occurring in the wild (3), the reinfestation that occurs following spraying with residual insecticides could be caused by the existence of residual foci or by passive conveyance of triatomines from adjacent infested communities $(10,11)$. In communities sprayed with organochlorine insecticides, the peridomiciliary area is one of the primary sources of $T$. infestans reinfestation $(12,13)$. In regard to the pyrethroids, whose residual power against triatomines is greater than that of the organochlorines, the peridomiciliary area could play the same role. No studies have yet been published that have identified the place of origin of T. infestans reinfestation or that examine its dynamics following application of pyrethroids in rural communities.

The study reported here was part of a broader project directed at optimizing Chagas' disease vector control programs. One of the project's aims was to identify the source of reinfestation and examine reinfestation dynamics at three typical rural communities of northeast Argentina after the communities were sprayed with deltamethrin. More specifically, the aim was to clarify whether the peridomiciliary area was the primary source of reinfestation.

\section{MATERIALS AND METHODS}

The study was conducted in the rural communities of Amamá, Trinidad, and Mercedes $\left(27^{\circ} \mathrm{S}, 63^{\circ} \mathrm{W}\right)$ in Moreno Department of Santiago del Estero Province in northern Argentina.
All three communities are located in a semiarid area where xerophilous quebracho forest predominates. Both their characteristics and the history of the infestation are described in other articles $(7,14)$. In March 1992, specimens of T. infestans were captured in $92 \%$ of the houses (15). The National Chagas' Service (Servicio Nacional de Chagas, SNCh) launched a spraying program in the rest of Moreno Department in 1993.

A house in the study communities typically had adobe walls, a thatched roof, one or two bedrooms, and a front porch. Such a residential structure, covered by a single roof, was defined as a domicile. The peridomiciliary area consisted of the yard, buildings not connected to the roof of the domicile (storerooms, kitchens, pens, etc.), and other potential vector hiding places (pieces of wood, trees, etc.) located within the area of human activity. Chicken coops, where existing, were constructed of poles placed near a tree where the chickens would sleep. Chickens, which were allowed to roam freely, would nest inside the house, in the peridomiciliary area, and in shrubbery located at varying distances from the home. Some $68 \%$ of all the domiciles had between three and eight peridomiciliary structures located less than $120 \mathrm{~m}$ away, and $56 \%$ had a domiciliary area greater than $70 \mathrm{~m}^{2}$.

In connection with this study, in October 1992 six technicians sprayed 90 inhabited dwellings and their peridomiciliary areas, one abandoned house, and 12 public facilities and other uninhabited structures (schools, churches, etc.). Members of the SNCh staff with extensive field experience participated in all phases of the study. A total of $69.6 \mathrm{~L}$ of flowable deltamethrin (K-Othrina, Farquimia, Argentina) was applied at an estimated rate of $25 \mathrm{mg}$ per $\mathrm{m}^{2}$ of sprayed surface. Laska pumps with Teejet 8002 tips (Laska, Argentina) were used to make the application, and standard procedures described elsewhere were followed (16). In December 1992 three more houses were sprayed, these being two abandoned residences and one home whose owner had previously expressed opposition to the spraying.
Twenty-four hours post-spray, two technicians and the residents of the houses involved collected the triatomines that had been knocked down.

The effectiveness of the spraying was assessed at 68 houses in early November 1992 through brief inspections (10 minutes per house) made by two technicians. Later, in mid-December of the same year, two technicians made a more intensive inspection (one person-hour per house). Searches were conducted using an irritant aerosol ( $0.2 \%$ tetramethrin, Icona, Argentina) to dislodge insects from their hiding places. Detected individuals and colonies were immediately sprayed using standard procedures.

In December 1992 anywhere from two to five biosensors were placed on the bedroom walls and halls of each house following previously described procedures (15). These biosensors were inspected at six-month intervals to detect triatomines or their excreta, eggs, or exuviae.

In May 1993 the residents of the study communities were given small reclosable plastic bags for capturing triatomines in the home or peridomiciliary area. These bags were subsequently inspected at six-month intervals, and residents were asked when and where they might have captured or seen triatomines.

In October 1993 and November 1994 two technicians using $0.2 \%$ tetramethrin as an irritant searched for triatomines in each domicile for 30 minutes while a third technician conducted a similar search of the peridomiciliary area. In May 1995 one technician using the same procedure spent 30 minutes searching for triatomines in each peridomiciliary area. Nearly all the T. infestans colonies detected on these occasions were immediately sprayed with deltamethrin; the only exceptions were two colonies that were sprayed with cypermethrin.

During the study's 30-month surveillance phase, eight houses were built within the study area; of these, it was possible to spray only four. Also, in November 1994 an infested logging operation was detected some $1500 \mathrm{~m}$ from Trinidad that could not 
be sprayed. However, between October 1993 and May 1994 thirteen houses in two peripheral settlements (Villa Matilde and Pampa Pozo) located outside the study area were evaluated and sprayed.

Captured triatomines were classified by species, and their degree of maturity, sex, place of capture, and date of capture were recorded. Data relating to captures of Triatoma guasayana and Triatoma sordida will be presented separately. Specimens that arrived at the laboratory alive were examined individually in order to determine whether they were infected with Trypanosoma cruzi. For this purpose, a few drops of fecal matter obtained by abdominal pressure were diluted on a slide holder with a few drops of saline solution and were then examined under the microscope at 400x.

The data presented in this article relate only to inhabited houses in Amamá, Trinidad, and Mercedes that were sprayed between October and December 1992, and those built in the same three villages subsequent to the initial spraying. They do not relate to houses located in the peripheral settlements that were sprayed after 1992.

For descriptive purposes, the term focus is defined as a place where at least one nymph and one adult $T$. infestans or more than two nymphs (i.e., a colony) were captured during a single evaluation. The foci detected in the study area were classified in accordance with density, age structure, and whether or not they had been sprayed, as follows. A preexisting focus was defined as one where several triatomines with different degrees of maturity were captured at a site that had not previously been sprayed. These foci were sprayed for the first time in December 1992. A site that had been sprayed before but where several triatomines with differing degrees of maturity were captured between November and December 1992 was classified as a residual focus. It appears that in these latter foci the insecticide had missed impacting the triatomines. Considering the length of the developmental stages of these insects, it can be inferred that the captured triatomine nymphs and adults were previously present in the focus and may have escaped the action of the insecticide (8). Places where $T$. infestans were found that had apparently been affected by the insecticide were not classified as residual foci. Finally, a new focus or recolonization site was defined as a place where a group of $T$. infestans was found for the first time.

Data on triatomine excreta obtained through the biosensors will be presented separately to avoid possible overestimation of the number of houses that were positive for T. infestans-because wild triatomines were also captured in study domiciles and peridomiciliary areas, and it was not possible to match the species to the excreta (15).

The association between the proportion of positive houses detected in each evaluation $(y)$ and the number of months following spraying $(x)$ was analyzed using a logistic regression model. (The infestation variable is binomial, and the possible values for the proportion of positive houses range between 0 and 1.) A house was considered positive when at least one $T$. infestans was captured (per manhour or resident) or when T. infestans eggs, exuviae, nymphs, or adults were collected by the biosensors in the house or peridomiciliary area.

\section{RESULTS}

The mass spraying carried out between October and December 1992 achieved a coverage of $98 \%$ (94 of 96 residences). It was not possible to spray two residences, either because the occupants could not be located or would not consent to the spraying. Two residual foci were detected in early November, and three more residual foci plus three preexisting foci were detected in late December (Table 1). Aside from one focus found in an abandoned house used by goats and pigs as a refuge, all of the foci were detected in peridomiciliary areas located between $15 \mathrm{~m}$ and $120 \mathrm{~m}$ from the corresponding domicile. The animals most frequently associated with these foci were chickens and goats. The abundance of $T$. infestans was three times greater in the preexisting foci than in the residual foci.

During the 30-month followup period, the percentage of residences where T. infestans eggs, exuviae,

TABLE 1. Location (village and type of site) of residual and preexisting T. infestans foci (the latter not sprayed in October 1992), the distance from the focus to a house, the usual vector hosts present, and the numbers of vectors (nymphs and adults) captured-either soon after an October 1992 application of deltamethrin (in November 1992) or almost two months later (in December 1992)

\begin{tabular}{|c|c|c|c|c|c|c|c|}
\hline \multirow[b]{2}{*}{ Foci } & \multirow[b]{2}{*}{ Village } & \multirow[b]{2}{*}{ Type of site } & \multirow{2}{*}{$\begin{array}{c}\text { Distance } \\
\text { from } \\
\text { house } \\
\text { (m) }\end{array}$} & \multirow{2}{*}{$\begin{array}{c}\text { Usual } \\
\text { vector hosts } \\
\text { present }\end{array}$} & \multicolumn{3}{|c|}{ Triatomines captured } \\
\hline & & & & & Nymphs & Adults & Total \\
\hline \multirow[t]{5}{*}{ Residuala } & Amamá & Pen ${ }^{b}$ & 50 & Pigs and chickens & 2 & 1 & 3 \\
\hline & Amamá & Chicken coop b & 60 & Chickens & 2 & 0 & 2 \\
\hline & Amamá & Drum & 20 & Cats & 8 & 0 & 8 \\
\hline & Trinidad & Tree in pen & 120 & Goats & 1 & 5 & 6 \\
\hline & Mercedes & Storage area & 17 & Unidentified & 1 & 10 & 11 \\
\hline Subtotal & & & & & 14 & 16 & 30 \\
\hline \multirow[t]{3}{*}{ Preexisting $^{c}$} & Amamá & Abandoned house & $\cdots$ & Pigs and goats & 5 & 25 & 30 \\
\hline & Trinidad & Kitchen & 15 & Chickens and pigs & 42 & 3 & 45 \\
\hline & Mercedes & Pen & 40 & Goats and chickens & 2 & 6 & 8 \\
\hline Subtotal & & & & & 49 & 34 & 83 \\
\hline
\end{tabular}

a Focal areas sprayed in October 1992.

${ }^{b}$ Foci detected in early November 1992; the rest were detected in late December 1992.

${ }^{c}$ Foci considered preexisting (with regard to the mass spraying) that were sprayed in December 1992. 
TABLE 2. Residences (domiciles and peridomiciliary areas) found positive for $T$. infestans following the October-December 1992 application of deltamethrin, showing the evaluation period involved; the numbers of residences evaluated; the numbers and percentages of residences where vector eggs, exuviae, nymphs, or adults were detected by biosensors, residents, or evaluators; the numbers of infested structures found in the domiciles and peridomiciliary areas; and the numbers of vectors captured in the domiciles and peridomiciliary areas

\begin{tabular}{|c|c|c|c|c|c|c|c|}
\hline \multirow{3}{*}{$\begin{array}{l}\text { Months after } \\
\text { spraying }\end{array}$} & \multicolumn{3}{|c|}{ Residences } & \multicolumn{2}{|c|}{$\begin{array}{c}\text { Number of } \\
\text { structures with } \\
\text { T. infestans in: }\end{array}$} & \multicolumn{2}{|c|}{$\begin{array}{l}\text { No. of } \\
\text { T. infestans } \\
\text { captured in: }\end{array}$} \\
\hline & \multirow{2}{*}{$\begin{array}{c}\text { No. } \\
\text { evaluated }\end{array}$} & \multicolumn{2}{|c|}{ Positive $^{a}$} & \multirow[b]{2}{*}{ Domicile } & \multirow{2}{*}{$\begin{array}{l}\text { Peridomi- } \\
\text { ciliary } \\
\text { area }\end{array}$} & \multirow[b]{2}{*}{ Domicile } & \multirow{2}{*}{$\begin{array}{c}\text { Peridomi- } \\
\text { ciliary } \\
\text { area }\end{array}$} \\
\hline & & No. & $(\%)$ & & & & \\
\hline 6 & 87 & $3^{b}$ & (3) & 0 & 0 & 0 & 0 \\
\hline 12 & 89 & 8 & (9) & 1 & 7 & 1 & $12^{c}$ \\
\hline 18 & 88 & 4 & (5) & 3 & 1 & 3 & $25^{c}$ \\
\hline 24 & 95 & 6 & (6) & 2 & 5 & 3 & $14^{c}$ \\
\hline 30 & 92 & 8 & (9) & 3 & 6 & 3 & $8^{d}$ \\
\hline Total & & & & 9 & 19 & 10 & 59 \\
\hline
\end{tabular}

nymphs, or adults were found (in either the domicile or the peridomiciliary area) remained consistently between $3 \%$ and $9 \%^{7}$ (Table 2). The number of peridomiciliary areas in which T. infestans was found (19) was more than double the number of domiciles (9) where it was found. Interestingly, T. infestans was found simultaneously in the domicile and peridomiciliary area of only two residences. In the peridomiciliary areas, 59 T. infestans (including 20 adults) were captured, while in the domiciles themselves only $10 \mathrm{~T}$. infestans (9 of them adults) were captured. In each evaluation conducted one year after the spraying, the number of $T$. infestans captured in the peridomiciliary areas was greater than the number captured in the domiciles. Seven percent $(1 / 15)$ of the $T$. infestans adults and none of the nymphs $(0 / 7)$ examined for T. cruzi were found to be infected with that agent.

Trees providing roosts for chickens or shelter for goats, together with

\footnotetext{
7 The logistical regression model constructed was as follows: $y=\exp (-3.087+0.022 x) /[1+\exp (-3.087$ $+0.022 x)] ; r=0.04 ; P=0.36$.
}

chicken coops made with poles, constituted the sites where $T$. infestans was found most frequently during the 1993-1995 surveillance period (Table 3). Indeed, some $64 \%(25 / 39)$ of the nymphs and $53 \%(29 / 55)$ of all the T. infestans captured were found in chicken coops. Overall, the surveillance indicated that chickens were the type of site creatures most frequently associated with infested structures.

Of the 15 peridomiciliary areas found infested (Table 3), 11 yielded only a single $T$. infestans, while five peridomiciliary areas associated with four houses yielded at least one nymph and one adult. These latter five colonies consisted of two persistent foci (the first located in a previously sprayed pigpen where two T. infestans had been captured earlier, and the second situated in a woodpile placed on the site considerably after the 1992 spraying) and three new foci found in a grain bin and two chicken coops.

During the five inspections of the 30month followup period, 23 residences were found positive for $T$. infestans on one occasion, five were found positive on two occasions, and one was found positive on three (Table 4). The inspections that found the residences positive a second time were conducted 24 and 30 months after the spraying. Only one of these residences was persistently positive in the three final evaluations, despite the fact that the peridomiciliary area was sprayed again during that period. The percentage of residences positive for the first time during the followup period reached its peak value $(9 \%)$ one year after the spraying, thereafter remaining in the range of $4-5 \%$.

TABLE 3. Sites of peridomiciliary foci detected during surveillance, customary $T$. infestans hosts present at or around each type of site, the numbers of peridomiciliary areas with foci at each type of site, and the numbers of $T$. infestans nymphs and adults captured at each

\begin{tabular}{|c|c|c|c|c|c|}
\hline \multirow{2}{*}{$\begin{array}{c}\text { Type of } \\
\text { peridomiciliary site }\end{array}$} & \multirow{2}{*}{$\begin{array}{l}\text { Customary hosts } \\
\text { present at site }\end{array}$} & \multirow{2}{*}{$\begin{array}{l}\text { No. of peridomiciliary } \\
\text { areas positive }\end{array}$} & \multicolumn{3}{|c|}{ Triatomines captured ${ }^{\mathrm{a}}$} \\
\hline & & & Nymphs & Adults & Total \\
\hline Trees & Chickens and goats & 5 & 2 & 3 & 5 \\
\hline Chicken coops made & & & & & \\
\hline with poles & Chickens & 3 & 25 & 4 & 29 \\
\hline Vehicle covers ${ }^{c}$ & Chickens & 1 & 0 & 1 & 1 \\
\hline Pens with covers & Pigs and chickens & 1 & 1 & 5 & 6 \\
\hline Grain bins & Chickens & 1 & 8 & 1 & 9 \\
\hline Woodpiles & Chickens & $2^{d}$ & 2 & 1 & 3 \\
\hline Wood fences & Chickens and turkeys & 1 & 0 & 1 & 1 \\
\hline Goat pens & Goats & 1 & 1 & 0 & 1 \\
\hline Total & & 15 & 39 & 16 & 55 \\
\hline
\end{tabular}


TABLE 4. Percentages of residences (including both the domicile and peridomiciliary area) found positive for $T$. infestans one or more times during the 30-month followup period

\begin{tabular}{|c|c|c|c|c|c|c|c|}
\hline \multirow{3}{*}{$\begin{array}{l}\text { Months after } \\
\text { spraying }\end{array}$} & \multirow{3}{*}{$\begin{array}{l}\text { No. of } \\
\text { residences } \\
\text { evaluated }^{\mathrm{a}}\end{array}$} & \multicolumn{6}{|c|}{ No. and percentage of residences ${ }^{b}$ positive for the: } \\
\hline & & \multicolumn{2}{|c|}{ First time } & \multicolumn{2}{|c|}{ Second time } & \multicolumn{2}{|c|}{ Third time } \\
\hline & & No. & $(\%)$ & No. & $(\%)$ & No. & (\%) \\
\hline 6 & 87 & 3 & (3) & & & & \\
\hline 12 & 89 & 8 & (9) & 0 & (0) & 0 & (0) \\
\hline 18 & 88 & 4 & (5) & 0 & (0) & 0 & (0) \\
\hline 24 & 95 & 4 & (4) & 2 & (2) & 0 & (0) \\
\hline 30 & 92 & 4 & (4) & 3 & (3) & 1 & (1) \\
\hline Total & & 23 & & 5 & & 1 & \\
\hline
\end{tabular}

${ }^{a}$ After October 1993 newly built houses were included. However, during each evaluation houses that were uninhabited or closed were excluded.

${ }^{\mathrm{b}} \mathrm{A}$ residence was considered positive if at least one live $T$. infestans (detected by an evaluator or resident) was found in the domicile or peridomiciliary area, or if at least one $T$. infestans, egg, or exuviae was found in a biosensor.

\section{DISCUSSION}

The study findings indicate that following mass application of deltamethrin, the peridomiciliary area was the place of origin of reinfestation. The percentages of peridomiciliary areas infested by $T$. infestans and the infestation densities were probably underestimated with respect to those of the domiciles, because less effort was made to capture triatomines in the peridomiciliary areas. In addition, since the peridomiciliary areas covered more area and their structures were more abundant and complex than those of the domiciles, one would expect the efficiency of the capture activities in the former areas to be relatively low.

Despite the good quality of the mass spraying, not all the $T$. infestans foci were eliminated. Such focal persistence has been observed repeatedly throughout the history of $T$. infestans control activities. In this regard, the presence of preexisting and residual foci may be attributable to coverage deficiencies or errors occasioned by such things as difficulty detecting potentially infested structures hidden under dense vegetation, refusal by some residents to have their homes sprayed, the presence of animals and food that could not be removed in order to conduct efficient spraying, etc. The abundance of the vector was greater in preexisting foci than in residual foci, suggesting that the former may be more important in promoting subsequent reinfestation if they are not treated promptly.

Initiation of the reinfestation process by $T$. infestans was detected less than one year after the spraying, as has been reported in other areas treated with pyrethroids $(5,6)$. In the areas of Santiago del Estero that were sprayed with deltamethrin and $\beta$-cypermethrin, the first persisting peridomiciliary infestations were recorded 60 days after spraying and were of low density (17). Our study suggests that this early reinfestation may have been attributable to the existence of residual foci.

A year after the spraying, five peridomiciliary foci were detected; there was also a forestry enterprise nearby and a number of infested houses that were located outside the study area. Nevertheless, the percentage of infested houses remained fairly stable (between 3\% and 9\%), and no domiciliary colonizations were recorded.

This stable condition characterized by a low degree of reinfestation may have been due to the combined effect of the initial spraying of peridomiciliary areas, spraying of the colonies detected during surveillance, and spraying in neighboring communities and other areas of Moreno Department (activities that lessened the chances for passive transport of triatomines). This inference was made after comparing our results with those obtained follow- ing a domiciliary spraying of Amamá alone with deltamethrin in September 1985 (7). In that study the percentage of infested domiciles increased exponentially, and after three years dense domiciliary colonies were found.

In contrast, our study found that many attempts at vector colonization (as indicated by the presence of $T$. infestans eggs, exuviae, nymphs, or solitary adults) were not followed by the appearance of new signs of infestation-even though no new control activities (aside from removal of captured triatomines and spraying of detected foci) were carried out. No colonies were found in locations where a solitary adult or nymph had previously been found, even though these locations were not sprayed again. Overall, these results suggest that recolonization is a process that meets with varying degrees of success in its initial stages. Among other things, mortality in the initial nymph instars appears quite high, and this reduces the vector's chances of reaching the adult stage and reproducing (2). These circumstances would tend to lead to spontaneous extinction of T. infestans populations in peridomiciliary areas where the vector density is very low.

Development of colonies in the peridomiciliary areas studied could have been related to the following factors: lack of ovicidal action by pyrethroids, which would promote recovery by the colonies; rapid loss of residual pyrethroid activity in the peridomiciliary areas, where the insecticides are more exposed to degradation by sunlight and leaching by rainwater; the lesser degree of orderliness and hygiene observed by residents outside the domicile; frequent addition of new (unsprayed) structures or materials originating in infested areas; the large relative expanse occupied by the peridomiciliary area around the house, which makes it the most likely site for the arrival of flying triatomines; the wide variety and large numbers of domestic animals found in peridomiciliary areas throughout the year; and the abundance of natural hiding places, such as chicken coop poles (containing holes) and trees used by 
chickens, which are difficult to reach with insecticides.

Chickens were triatomine hosts typically found throughout the peridomiciliary areas, including near the fences of pig and goat pens. In other areas, goat pens-constructed largely of shrub branches-have often been found abundantly infested with $T$. infestans $(12,18)$. The structure of the coops and pens, together with a permanent presence of hosts, could favor the continuing existence of peridomiciliary triatomine populations as well as domiciliary recolonization after spraying.

By and large, the feeding profile of $T$. infestans reveals that chickens are the vector's primary source of food $(19,20)$. In the study area, the wide distribution and great abundance of chickens in the peridomiciliary areas would help to explain why only one of $22 T$. infestans examined were infected with T. cruzi, a level of positivity similar to the level found prior to spraying (3.8\%, unpublished results).

The findings of this study can probably be extrapolated to other rural parts of the Americas with comparable peridomiciliary areas, to different species of triatomines colonizing both domiciliary and peridomiciliary areas, and to other pyrethroids used for triatomine control.

Clearly, elimination of $T$. infestans from rural communities requires more than mere reduction of vector density and interruption of T. cruzi transmission. Indeed, $T$. infestans elimination can be achieved only by a sustained and integrated control program enjoying substantial community participation and providing good coverage of the peridomiciliary area. Such a program should incorporate chemical control, environmental management, and surveillance activities directed specifically at the peridomiciliary area. These activities should include detection and elimination of residual or untreated foci; use of an insecticide that is not as degradable by climatic factors or repeated insecticide applications 6 to 12 months after the initial spraying; introduction of environmental modifications aimed at reducing the availability of peridomiciliary hiding places; restriction of poultry breeding to structures not suitable for triatomine colonization; increased efforts to detect $T$. infestans during the surveillance phase (although a tool for the passive and ongoing detection of triatomines in the peridomiciliary area has been described (21), no data are available as to its efficacy); and promotion of environmental orderliness and cleanliness among the target population with greater than customary frequency.

Acknowledgment. This study was funded by the University of Buenos Aires and the Alberto J. Roemmers Foundation. In addition, a subsidy was received from the Rockefeller Foundation, through the Rockefeller University (New York), for use in a companion project on "Modeling Transmission and Control of Chagas' Disease" (primary researchers: Roberto Chuit, Joel E. Cohen, and Ricardo Gürtler). The authors wish to thank Abel Hurbitz (Director), Emilio Vigil, Griseldo R. Roldán, Isaac Ochoa, and other National Chagas' Service technicians, as well as Omar Citatti, María Mayano, and other residents of the study area for their participation in this effort. Joel E. Cohen extends his thanks to William T. Golden and his wife for their hospitality during this assignment. The participation of Joel E. Cohen was funded in part by grant BSR 92-07293 from the U.S. National Science Foundation.

\section{REFERENCES}

1. Schofield CJ. Population dynamics and control of Triatoma infestans. Ann Soc Belge Med Trop 1985;65(Suppl 1):149-164.

2. Rabinovich JE. Vital statistics of Triatominae (Hemiptera: Reduviidae) under laboratory conditions; I. Triatoma infestans (Klug). J Med Entomol 1972;9:351-370.

3. Canale DM, Carcavallo RU. Triatoma infestans (Klug). In: Carcavallo RU, Rabinovich JE, Tonn RJ, eds. Vol 1: Factores biológicos y ecológicos en la enfermedad de Chagas. Buenos Aires: Servicio Nacional de Chagas (Argentina); 1985:237-250.

4. Organización Mundial de la Salud. Encuentro latinoamericano sobre "sistemas de vigilancia para evaluar el impacto de los programas de control de la enfermedad de Chagas," Córdoba, 25-29 November, 1991. Geneva: OMS; 1991. (Document TDR/CHA/EVA 91.3).

5. Pinchin R, Oliveira Filho AM, Fanara DM, Gilbert B. Ensaio de campo para avaliação 1986;81(Suppl):171. das posibilidades de uso da decametrina (OMS 1988) no combate a triatomíneos. Rev Bras Malariol Doenças Trop 1980;32: 36-41.

6. Oliveira Filho AM, Santos CE, Melo TMV, Figuereido MJ, Silva EL, Dias JCP, et al. Field trial of insecticides in an area of high levels of infestation and dispersion of Triatoma infestans. Mem Inst Oswaldo Cruz

7. Gürtler RE, Petersen RM, Cecere MC, Schweigmann NJ, Chuit R, Gualtieri JM, et al. Chagas' disease in north-west Argentina: risk of domestic reinfestation by Triatoma infestans after a single community-wide application of deltamethrin. Trans R Soc Trop Med Hyg 1994;88:27-30.

8. Paulone I, Chuit R, Pérez A, WisniveskyColli C, Segura EL. Field research on an epidemiological surveillance alternative of Chagas' disease transmission: the primary health care (PHC) strategy in rural areas. Rev Argent Microbiol 1988;20 (Suppl):103-105.

9. Chuit R, Paulone I, Wisnivesky-Colli C, Bo R, Pérez A, Sosa-Estani S, et al. Results of a first step toward community-based surveillance of transmission of Chagas' disease with appropriate technology in rural areas. Am J Trop Med Hyg 1992; 46:444-450.

10. Soler CA, Schenone H, Reyes H. Problemas derivados de la reaparición de Triatoma infestans en viviendas desinfestadas y el concepto de reinfestación. Bol Chil Parasitol 1969;10:83-87.

11. Chuit R. Epidemiología de la enfermedad de Chagas en áreas rurales de Argentina. [Doctoral thesis]. Córdoba: Universidad Nacional de Córdoba; 1989.

12. Soler CA, Knez NR, Neffen LE. Importancia del estudio de los factores socioeconómicos en la enfermedad de ChagasMazza: La Rioja; focos peridomésticos. La 
Rioja, Argentina: Servicio Nacional de Chagas-Mazza; 1977.

13. Dias JCP. Reinfestação do município de Bambuí por triatomíneos transmissores da doença de Chagas. Mem Inst Oswaldo Cruz 1967;66:197-208.

14. Gürtler RE, Cecere MC, Rubel DN, Schwigmann NJ. Determinants of the domiciliary density of Triatoma infestans, vector of Chagas' disease. Med Vet Entomol 1992;6:75-83.

15. Gürtler RE, Chuit R, Cecere MC, Castañera MB. Detecting domestic vectors of Chagas' disease: a comparative trial of six methods in north-west Argentina. Bull World Health Organ 1995;73:487-494.

16. Gualtieri JM, Ríos CH, Cichero JA, Váez R, Carcavallo RU. Ensayo de campo con decametrina en su formulación líquida emulsionable y floable en el control del
Triatoma infestans en la Provincia de Córdoba. Chagas (Argentina) 1984;1:17-20.

17. Wallace G, Zerba E, Wood E, Casabe N, Martínez A, Hurvitz A, et al. Ensayo de campo de asimetrina, un nuevo piretroide de alto efecto triatomicida. Medicina (Buenos Aires) 1993;53(Suppl 1):74.

18. Ronderos RA, Schnack JA, Mauri RA. Resultados preliminares respecto de la ecología de Triatoma infestans (Klug) y especies congenéricas con referencia especial a poblaciones peridomiciliarias. Medicina (Buenos Aires) 1980;40(Suppl 1): 187-196.

19. Wisnivesky-Colli C, Gürtler RE, Solarz ND, Salomón DO, Ruiz AM. Feeding patterns of Triatoma infestans (Hemiptera: Reduviidae) in relation to transmission of American Trypanosomiasis in Argentina. J Med Entomol 1982;19:645-654.
20. Gürtler RE, Cecere MC, Vázquez DP, Chuit R, Cohen JE. Host-feeding patterns of domiciliary Triatoma infestans (Hemiptera: Reduviidae) in northwest Argentina: seasonal and instar variation. $J$ Med Entomol 1996;33:15-26.

21. García-Zapata MTA, Marsden PD. Chagas' disease: control and surveillance through use of insecticides and community participation in Mambaí, Goiás, Brazil. Bull Pan Am Health Organ 1993, 27:265-279.

Manuscript received on 13 November 1995. Revised version accepted for publication on 27 February 1996.

RESUMEN El objetivo del estudio fue identificar el origen y estudiar la dinámica de la reinfestación por Triatoma infestans ocurrida después de rociar con deltametrina el domicilio y peridomicilio de 94 casas de tres comunidades rurales el noroeste argentino. La efectividad del rociamiento se evaluó inmediatamente después y al segundo mes de rociar las viviendas. Además, se detectaron y rociaron 5 focos residuales peridomiciliarios y 3 preexistentes que no habían sido rociados. Para monitorizar la reinfestación, se colocaron biosensores en los domicilios, se solicitó a cada familia que capturase triatominos y los guardara en bolsas de plástico, y se buscaron triatominos en domicilios y peridomicilios usando un aerosol para desalojar a los insectos de sus refugios. Solo se realizaron rociamientos selectivos donde se encontró alguna colonia de T. infestans. Durante 30 meses de seguimiento, el porcentaje de casas donde se capturó algún T. infestans osciló entre 3\% y 9\%. En 6 casas se capturaron T. infestans en más de una evaluación. El número de peridomicilios infestados (19) fue el doble que el de domicilios (9). Solo se detectaron colonias de T. infestans en peridomicilios. La cifra de T. infestans capturados en peridomicilios fue seis veces más alta que la de los domicilios. Las gallinas fueron el hospedador más frecuentemente asociado con los focos peridomiciliarios. El peridomicilio constituyó el origen y la principal fuente de reinfestación. Para reducir la velocidad de reinfestación y la frecuencia de rociamientos es preciso combinar medidas de manejo ambiental y control químico en los peridomicilios: reducir los refugios para triatominos; restringir la cría de aves a estructuras no colonizables por triatominos; aplicar un insecticida menos degradable por agentes climáticos o realizar un segundo rociamiento de 6 a 12 meses después del primero, y emplear un dispositivo para detectar tempranamente la presencia de T. infestans en peridomicilios. 